\title{
Nyugdíjas korúak szabadidejének strukturális vizsgálata
}

\section{Structural Analysis}

of senior citizens' leisure time

\author{
Dr. Princz Adrienn - Dr. Tessényi Judit
}

\section{Összefoglalás:}

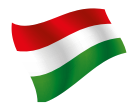

Számos magyarországi társadalmi kérdés közül a nyugdíjas korúak szabadidő-összetételére végeztünk primer kutatást. Mint korábban erre vonatkozó vizsgálatok és tanulmányok már jelezték, a várható élethosszat és életminőséget nagymértékben meghatározza a szabadidő szellemi és fizikai eltöltésének mikéntje. Mivel a nyugdíjas kor elértével nagymértékben megváltozik a szabadidő mértéke és az ébren eltöltött órák hasznosítása, arra a kérdésre kerestük a választ, hogy ebben az életszakaszban a szellemi és fizikai rekreáció mennyire tudatos, milyen összetételủ és bizonyos szociális körülmények mennyiben mutatnak összefüggést egymással. Vajon van-e egy családi traumának szerepe az időskori életmódváltásban? Kérdőíves kutatásunkat egy szakértői mélyinterjúval bővítettük, és küldtük ki a vizsgált korcsoportnak. Előzetes eredményeket összegeztük, melyek igazolták, sőt egyes esetekben meg is haladták várakozásainkat a válaszadóink aktivitására vonatkozóan, amelynek következményeként mind szellemi, mind pedig fizikai rekreációs tevékenységeikben nagyon változatos képet mutattak.

Abstract:

From among the many societal questions of Hungary, we have conducted primary research on the composition of the free time of retired persons. As indicated previously by relevant studies and analyses, life expectancy and expected quality of life are greatly influenced by the manner in which free time is passed both physically and mentally. Due to the fact that with reaching the retired age, the extent of free time and making use of the hours spent awake significantly changes, we are looking for answers to the question how conscious physical and mental recreation is in this phase of life, how is it composed, and how do different social circumstances - such as circumstances of the life of the retired - relate to each other. Does a family trauma have an effect on changing the way of life in old age? We have chiselled our questionnaire-based research with an in-depth expert interview and have distributed it within the age group examined. We then summarised the preliminary results, which evidenced and in some cases even surpassed our preliminary findings in terms of the activity of our respondents. As a result of this, our respondents have pained a very colourful picture about their recreational activities, both in mental and in physical terms.

Kulcsszavak: rekreáció, szabadidő, nyugdíjas

\section{Előzmények}

A XX. század olyan demográfiai, társadalmi, technikai, valamint gazdasági folyamatokat indított el, amelynek eredményeként a harmadik évezred elejére 3 nagyon komoly robbanás határozza meg alapjaiban a ma elő emberek életét: jelenlegi ismereteink szerint soha nem éltek annyian és ilyen hosszú ideig ezen a bolygón, és soha enynyi információ sem állt a felhasználók rendelkezésére, mint napjainkban (Iván, 2005). Ezeknek a változásoknak a következményeként a
XXI. század egyik legfontosabb társadalmi és gazdasági kihívása úgy világ-, mint uniós, illetve tagállami szinten az idősödés, hiszen a jelenlegi tendencia szerint 2025 -re az európai polgárok több mint $20 \%$-a 65 éves vagy annál idősebb lesz, ráadásul a 80 éves kort megélt emberek száma is jelentősen fog emelkedni (Európai Bizottság, 2016).

A nyugdíjas korú népesség számának ilyen mértékű növekedése nemcsak az államok egyes ellátórendszerének mindennapos múködésére gyakorol jelentős hatást (Bodrogi, 2009), hanem a gazdasági és társadalmi életre éppúgy, mint az egyéni és közösségi szintre. Éppen ezért már nemcsak jelenleg, hanem távlatokban, globális szinten is komoly paradigmaváltásra van szükség (Iván, 2005) ahhoz, hogy életünk ún. harmadik életszakaszát ${ }^{2}$ aktívan, tartalmasan tudjuk eltölteni.

A nyugdíjas korú népesség számának emelkedése hazánkban is az európai tendenciához hasonló mértékben alakult. Mindenképpen pozitív, hogy - ahogyan az 1. számú táblázatból megállapítható - az elmúlt évszázad során a születéskor várható átlagos élettartam mind a férfiak, mind pedig a nők körében a duplájára nőtt ${ }^{3}$.

\begin{tabular}{|l|c|c|}
\hline \multicolumn{3}{|c|}{ Születéskor várható átlagos élettartam } \\
alakulása \\
\hline Év & Férfiak & Nök \\
\hline $1900-1901^{1}$ & 36,6 & 38,2 \\
\hline $1930-31$ & 48,7 & 51,8 \\
\hline 1960 & 66,4 & 70,6 \\
\hline 1990 & 65,1 & 73,7 \\
\hline 2010 & 70,7 & 78,6 \\
\hline 2015 & 72,1 & 78,6 \\
\hline
\end{tabular}

1. táblázat:

Születéskor várható átlagos élettartam (Forrás: KSH)

Ezen folyamatok következményeként nemcsak az figyelhetö meg, hogy 2014-re a magyarországi népesség 60 év feletti lakosainak aránya a teljes népesség 24,4\%-át érte el (Demográfiai évkönyv, 2014), hanem ahogyan az a 2. számú táblázat adataiból egyértelmủen megállapítható, ezzel a folyamattal párhuzamosan, maga a népesség összetétele is jelentősen megváltozott.

1) Magyarország 1920 előtti területén, Horváth-Szlavonország nélkül.

2) Eddigi kutatásaink során megállapíthatjuk, hogy nincs általánosan elfogadott, egzakt módon meghatározott definíció a harmadik életszakaszra. E tanulmány harmadik életszakasz alatt a jellemzően nyugdíjba vonulást követő teljes időszakot érti. Amennyiben összehasonlítjuk az időskor fogalmát például az Egészségügyi Világszervezet által meghatározott életkor szerinti felosztásával, akkor arra a megállapításra juthatunk, hogy maga a korszak további szempontok alapján tovább csoportosítható, ahol a "harmadik kor” egy önálló időszakot fed le.

3) Ugyanakkor elkeserítő, hogy ez az érték a férfiak esetében közel 10, a nők esetében pedig közel 7 évvel marad el az élvonalba tartozó országok értékeitől. 


\begin{tabular}{|c|c|c|c|c|}
\hline \multicolumn{5}{|c|}{ A népesség föbb korcsoportok szerint } \\
\hline \multirow{2}{*}{ Mérési időpont } & $\mathbf{0 - 1 4}$ & $\mathbf{1 5 - 3 9}$ & $\mathbf{4 0 - 5 9}$ & $\mathbf{6 0}$ - \\
\cline { 2 - 5 } & \multicolumn{5}{|c|}{ és (százalékos megoszlás) } \\
\hline \multirow{2}{*}{$1900-1901^{1}$} & 34,9 & 38,7 & 18,9 & 7,5 \\
\hline $1930-1931$ & 27,5 & 42,6 & 20,1 & 9,8 \\
\hline 1960.01 .01 & 25,4 & 36,8 & 24,1 & 13,8 \\
\hline 1990.01 .01 & 20,5 & 35,5 & 25 & 18,9 \\
\hline 2010.01 .01 & 14,7 & 35,5 & 27,2 & 22,5 \\
\hline 2014.01 .01 & 14,4 & 33,6 & 27,6 & 24,4 \\
\hline
\end{tabular}

2. táblázat:

A népesség föbb korcsoport szerinti megoszlása százalékos mértékben (Forrás: KSH)

Míg egyik oldalról a 0-14 éves korosztály részaránya egy évszázad alatt igen komoly mértékben, több mint 20 százalékponttal csökkent, addig másik oldalról a 60 éves vagy idősebb korosztálybeliek száma közel megötszöröződött. ${ }^{4}$

„Ennek a folyamatnak az egyik lényeges következménye az, hogy a ma időskorba kerülőknek egyre kevesebb gyermeke, egyre kevesebb unokája van, miközben ők maguk is különböző gyermekszámú családból származnak, kevesebb hozzájuk hasonló korú testvérük és unokatestvérük van, a kiterjedt családi támogató rendszer egyre kevesebb személyre korlátozódik, a megnövekedett földrajzi mobilitás pedig még ezt a kisebb létszámú családot is megosztja földrajzilag és végül, de nem utolsósorban a kapcsolatok szükülésével a szubjektív, informális és érzelmi alapon nyújtott támasz fogyatkozik, és ez csupán anyagi eszközökkel nem helyettesíthetö" (Iván, 2002, 413. o.).

Az egyéni és a közösségi szint megléte, az erre történö megfelelő odafigyelés véleményünk szerint kardinális kérdés. „Szemben ugyanis a biológiai történések fokozatos menetével, az öregségbe való pszichikus átlépés mindig fordulatszerü. Az öregség fordulópontja nem köthető tipikus életkorhoz vagy jellemző eseményhez, ez az ember szubjektív történelmének egyéni krízise, mely az érintetteket szinte »rajtaütésként« keríti hatalmába" (Fritz, 2011, 182. o.).

A harmadik életszakasz eltöltésének minőségét alapvetően az a körülmény fogja jelentősen meghatározni, hogy ennek a generációnak a tagjai tudatosan mennyire képesek alkalmazkodni az új életkörülményeihez, mennyiben tudják megőrizni mind fizikai, mind pedig lelki egészségüket, és ezzel összefüggésben szellemi frissességüket úgy, hogy közben jelentős mértékben megváltozik a rendelkezésükre álló szabadidő mértéke, a társas kapcsolatok szerepe és jellege és ezek következményeként az ébren eltöltött órák kihasználtsága (Nagyváradi és tsi., 2012).

A Központi Statisztikai Hivatal 1963 óta 10 évente vizsgálja a magánháztartásokban élő 10-84 éves népesség időfelhasználását és ennek összetételét. Az utolsó adatfelvételre 2009. október 1. és 2010. szeptember 30. között került sor, amelynek keretében hagyományosan az alábbi 3 tevékenységcsoportot vizsgálnak: (i.) társadalmilag kötött tevékenységek, (ii.) fiziológiailag kötött tevékenységek, (iii.) szabadon végzett tevékenységek (Bárdosi - Tabajdi, 2013).

A résztvevők időfelhasználásának jellemzésére három mutató szolgál, amelyek közül e tanulmány szempontjából releváns „A” mutató ${ }^{5}$ érékeit tekintettük kiindulási alapnak. Továbbá mivel „,a szabadidős tevékenységeknek nemcsak a hosszát, de a struktúráját is jelentősen befolyásolja az életkor" (Bárdosi - Tabajdi, 2013, 8. o.), ezért a továbbiakban kizárólag a vizsgált népesség magát nyugdíjas korúnak valló résztvevőinek értékeit tanulmányoztuk.

A KSH felmérésében a nyugdíjas korú megkérdezettek szabadon végezhető tevékenységére napi szinten átlagosan az idejük 23,2\%-a jut. Ebből kicsivel több mint 60\%-át töltik átlagosan tévénézéssel, videózással, valamint internetezéssel, amely napi szinten átlagosan több mint 3 órás passzív tevékenységet jelent. Ehhez képest naponta csupán átlagosan 14\%-ban van jelen a szabadidő társas elöltése, 10\%-ban az olvasás, 5,7\%-ban valamiféle hobbi jellegü tevékenység, és csupán 4,5\%-ban van jelen bármilyen aktív tevékenység (sport, kirándulás, testedzés).

\section{Hipotézisek}

A KSH időmérleg tanulmányának értékeit alapul véve feltételeztük, hogy a vizsgált korcsoport mindennapjaiban a rendszeres testmozgás alig, vagy csak minimális mértékben lesz jelen.

A fentieket alapul véve feltételeztük, hogy hazánk jelenleg nyugdíjas korú lakosainak életkörülményét, életminőségét, és ezzel szoros összefüggésben a szabadidejét jelentősen befolyásolja a környezete, családja, baráti köre; a mindennapokat már jelentősen meghatározó telekommunikációs eszközök ismerete és használata, ezáltal pozitív hatást gyakorolva a mindennapi életükre.

Figyelembe véve a 2009/2010-es időmérleg-tanulmány adatai alapján elkészült Kulturális szokásaink címü kiadvány megállapításait, abból a feltevésből indultunk ki, hogy a szellemi-kulturális programok körében a nyugdíjas korúak szabadidejében az olvasás lesz a legmeghatározóbb időtöltési mód. ${ }^{6}$

\section{Módszertan}

Ahhoz, hogy hipotéziseink minél jobban igazodjanak a napjaink magyar nyugdíjasainak valós tapasztalataihoz, mélyinterjút készítettünk Hegyesiné Orsós Évával, a Nyugdíjasklubok és Idősek „Életet az Éveknek" Országos Szövetségének elnökével, akinek értékes észrevételei segítették jelen tanulmány alapjául szolgáló kérdőív összeállítását. Ezen beszélgetés alapján szerzett ismeretek eredményeként 6 fö témakör került meghatározásra, amelyek álláspontunk szerint alkalmasak arra, hogy e kutatás során meghatározott célkitüzéseinket igazolják, vagy esetlegesen éppen cáfolják:

1.) aktív tevékenységek köre;

2.) életkörülmények;

3.) egészség;

4.) motiváció;

5.) napi teendők;

6.) egyéb.

Kérdőívünk részben kötött, mivel olyan kérdéseknél, ahol az adott válasz függvényében több alternatív irány indítása lehetséges, kötelező válaszadást kértünk. Bizonyos esetekben több lehetséges válasz is megjelölhető volt, illetve több kérdésnél meghatározásra került az „egyéb” kategória, amely segítségével a válaszadó röviden megoszthatta saját, a kérdéstöl esetlegesen eltérő válaszát.

Kutatásunk célja a nyugdíjas korú népesség szabadidö-eltöltésének vizsgálata egy nagyobb volumenü kérdőíves felméréssel. Ennek az adatfelvételnek az előkészítésére előzetes vizsgálatot végeztünk, amelynek célja további kutatás kijelölése, a szerzett tapasztalatok alapján a hipotézisek, valamint a kérdőív esetleges pontosítása, és annak meghatározása, hogy a továbbiakban mit lenne érdemes még vizsgálni.

Próbafelvételünk 2016. október 1. és 2016. október 15-e között zajlott, anonim módon, interneten keresztül. Az összeállított kérdőív a Google, Google Drive funkciójának, Google ürlapok elérhetőségeként jelen lévő, kérdőíves adatfelvételre is használható funkciója segítségével készült el és lett közzétéve.

Ezen előzetes adatfelvétel során közzétett kérdőívhez tartozó link részben olyan internetes fórumokon lett közzétéve, amely nagyobb nyugdíjas taglétszámmal rendelkezik, részben pedig a hólabda módszerủ mintavételt alkalmaztuk.

4) 1900-ban a 7,5\% 514080 főt, míg 2014-ben a 24,4\% 2411429 föt jelentett.

5) „A” mutató: egy főre jutó átlagos napi időráfordítás (percben) a teljes vonatkozási körre számolva, függetlenül attól, hogy az adott sokaságból ténylegesen hányan végezték a vizsgált napon az adott tevékenységet. Az „A” mutató esetében az összes végzett tevékenység együttes ideje 1440 perc, azaz 24 óra. (Időmérleg, 2012. 5. o.).

6) Előzetesen kutatás nem tér ki a tévénézésre, mint a szabadidő eltöltésének egyik lehetséges módjára. 
Kérdőívünk anonim jellege miatt a hólabda módszeres mintavétel alkalmazása az adatfelvétel során részben igazolást nyert, mivel korábbi tapasztalataink szerint a face to face kitöltések és a kérdezőbiztosok bevonása - a felmerülő többlet kutatási költség mellett - esetenként a válaszadók torzított, befolyásolt vagy egyszerüen megfelelési vágyból módosított válaszait eredményezte. Ezen előzetes vizsgálat azonban több ponton rávilágított arra, hogy esetenként nagyobb arányban kaptunk meglepően őszinte, önkritikus választ, amelyet mindenképp pozitívumként értékelünk.

Mivel jelen próbavizsgálat alapját képező kérdőívet összesen 157, az internetet valamilyen formában rendszeresen használó nyugdíjas töltötte ki, ezért a tanulmány csak az internethasználó nyugdíjasok szabadidőszokásaira tud iránymutatásként szolgálni, így következtetéseinket kizárólag erre a csoportra lehet vonatkoztatni.

A beérkezett kérdőívek adatainak feldolgozását SPSS 23.0-ás verziójú statisztikai csomagjával végeztük. A kapott adatokon alapuló megállapításainkat pedig folyamatleíró-elemző értékelési rendszer szerint mutatjuk be, azzal, hogy ahol lehetőség van, ott a kapott ténymegállapításoknál kitekintünk más, nagyobb volumenü, reprezentatív kutatás eredményére.

\section{Kutatási eredmények}

Arra a kérdésünkre, hogy napi rendszerességgel végez-e testmozgást, a válaszadóink 75,2\%-a felelt igennel.

„A műveltségnek (iskolázottságnak) az életmódra és a szabadidőre gyakorolt hatását vizsgálva szociológusok megállapították, hogy a tudományos kutatókra jellemző a legsokoldalúbb szabadidőgazdálkodás, ezen belül a rendszeres sportolás, kirándulás igénye és gyakorlata" (Fritz, 2011. 16. o.). Kutatásunk a megkérdezettek végzettségét ilyen mélységben ugyan nem vizsgálta, de figyelembe véve a KSH 2011-es népszámlálásának adatait, valamint e kutatás alapját képező kérdőív kitöltőinek végzettségi adatait (a válaszadók többsége rendelkezik föiskolai vagy egyetemi diplomával), ez a megállapítás adaptálható tanulmányunk előzetes adataira is. Álláspontunk szerint a másik meghatározó körülmény ennek a viszonylag magas értéknek az elérésében az volt, hogy a válaszadók - 150fö - 61-65 év közötti, azaz éppen most kezdte meg nyugdíjas éveit, és ugyanekkora arányban válaszoltak a 66-75 éves korcsoportba soroltak is (1. számú ábra), akik ugyan már nem friss nyugdíjasok, de aktívan tudják élni a mindennapjaikat.

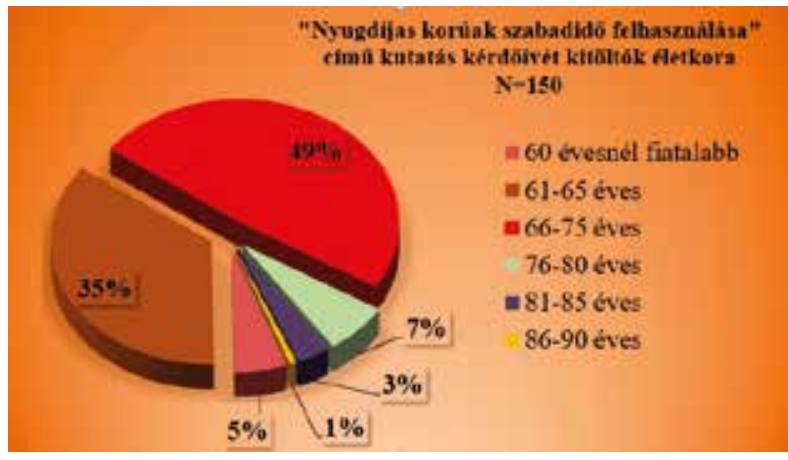

1. ábra

Internetes adatfelvétel miatt számítottunk arra, hogy kérdőívet kitöltők között magas lesz azoknak az aránya, akik valamilyen gyakorisággal használnak számítógépet, valamint, hogy nagyon magas a modern technikát használók aránya. Válaszadóink 98\%-a rendelkezik mobiltelefonnal, és 92\%-a számítógéppel. A kérdőívet kitöltők ráadásul nemcsak rendelkeznek számítógéppel, hanem, ahogyan az a 2. számú ábrából egyértelmủen megállapítható, ugyanilyen arányban használják is az internetet (94\%), valamint valamilyen elektronikus levelezést $(87,2 \%)$ is müködtetnek. Meghatározó továbbá az a körülmény is, hogy a válaszadók $76,5 \%$-a részese valamilyen internetes közösségi fórumnak.

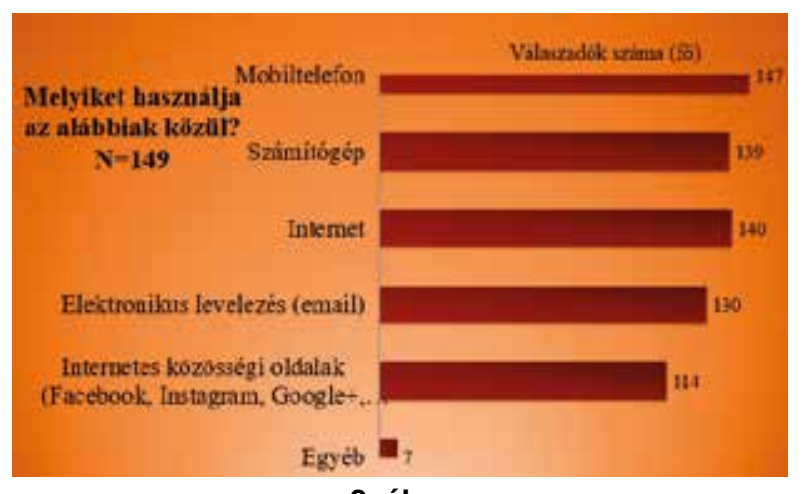

2. ábra

A fizikai aktivitás, valamint az internetes közösségi oldalak rendszeres használatának magas értéke véleményünk szerin elősegíti a társas érintkezést, csökkentve az erre a korosztályra veszélyes elmagányosodás lehetőségét. ${ }^{7}$ 3. ábra

Rendszereșen milyen jellegũ tevékenységet folytat? - Tơbb válasz is bejelöthetô.-

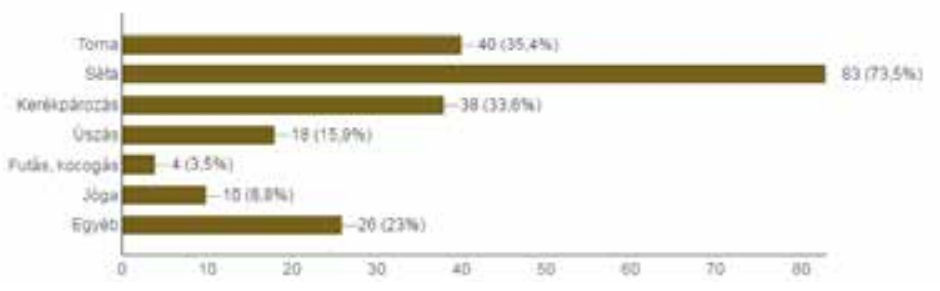

\section{3. ábra}

Ahogyan a 3-as számú ábra alapján megállapítható, válaszadóink legnépszerúbb mozgásformája a séta $(73,5 \%)$, második helyen a torna $(35,5 \%)$, míg harmadik helyen a kerékpározás áll $(33,6 \%)$. Egyértelmúen megállapítható, hogy a három legnépszerübb mozgásforma közül kettő, a séta illetve a biciklizés, akár önálló tevékenységként, akár a mindennapos feladatok elvégzése érdekében végzett tevékenységek részeként beilleszthetőek a mindennapokba. Az úszás, a futás, illetve a jóga ugyanakkor tipikusan azon aktív tevékenységek közé tartozik, amelyeket otthon nem, vagy csak ritkán végezhetnek, illetve, amelyek, nagyobb esetben jelenthetnek rendszeres pluszkiadást. Ugyanakkor az is tény, hogy ebben az életszakaszban már nagyobb eséllyel fordulhatnak elő olyan betegségek, amelyek egyszersmind gátolhatják ezeket az aktívabb mozgásformák (jellemzően: futás-úszás) végzését. Tekintettel arra a tényre, hogy 115 válaszadónk $58,2 \%$-a osztotta meg velünk, hogy egészségi problémája befolyásolta/befolyásolja az életvitelét, ráadásul ez a változás inkább negatív irányú volt, ezért azt nem tudtuk megállapítani, hogy az alacsonyabb, kisebb terheléssel járó mozgásformák inkább egészségi okok miatt, vagy inkább költséghatékonyság miatt preferáltak.

Az előzetes mélyinterjú megerősített bennünket abban, hogy a nyugdíjas korúak esetén is lényeges - az életminőség szempontjából befolyásoló tényező -, hogy van-e törödést igénylő a környezetében. Ebben a kérdéskörben 154 válaszadónk 51,3\%-a válaszolta, hogy van rendszeres figyelmet, foglalkozást igénylö hozzátartozója (házastárs, szülö, testvér, gyermek), és 111 válaszadónk 32,4\%-a tart valamilyen háziállatot.

Ahogyan azt korábban előzetesen jeleztük, a szellemi szabadidős tevékenységek közül az olvasás a legnépszerübb, válaszadóink fele napi rendszerességgel olvas. Ugyanakkor $43 \%$ soha nem jár moziba, $23 \%$-uk pedig évente egyszer látogat el színházba. Sajnos 47,3\%-nak nincs semmilyen hobbija, és akinek van, azok közül is csak $23 \%$ üzi azt legalább heti rendszerességgel. Viszont társas összejövetelekre elmegy heti gyakorisággal 52,3\%. A kiállítás látogatására vonatkozó kérdésünkre a 2-3 havi válasz fordult elő a leggyakrabban $(29,2 \%)$.

7) v.ö. Iván, 2005, 14-15. o. 
Közel megegyező az olvasással a keresztrejtvényt fejtés rendszeressége, és heti szinten a kertészkedés. Soha vagy évente egyetlen alkalommal kirándul megkérdezett nyugdíjasaink 19\%-a, viszont havonta többször 23,5\%-uk. Az egyéb hobbitevékenységre nagyon diverzifikált válaszok érkeztek - a teljesség nélkül ezeket az 1. számú képen összeállított szófelhőbe gyüjtöttük.

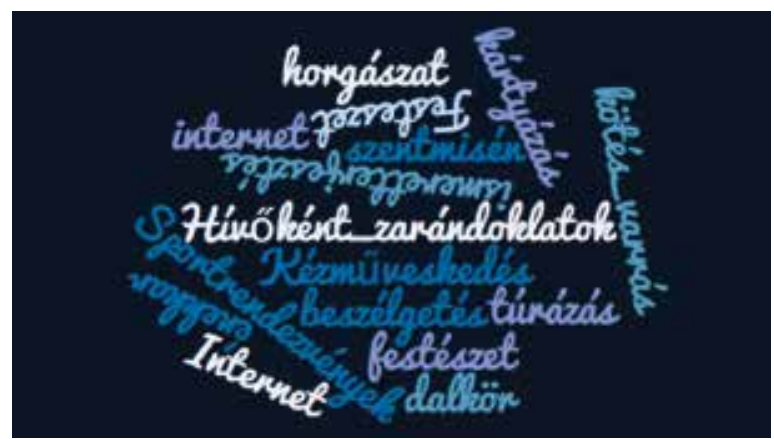

1. kép: Szófelhő az egyéb hobbitevékenységekröl

Az elózetes adatokból az is megállapítható, noha a megkérdezettek $41 \%$-a él egyedül - 96\%-ban saját otthonukban, mégis jelentős többségük rendelkezik olyan állandó napi feladattal, amely nemcsak leköti őket, hanem többségük, ahogyan az a 4. ábrán is látható, elégedett ezzel a tevékenységével.

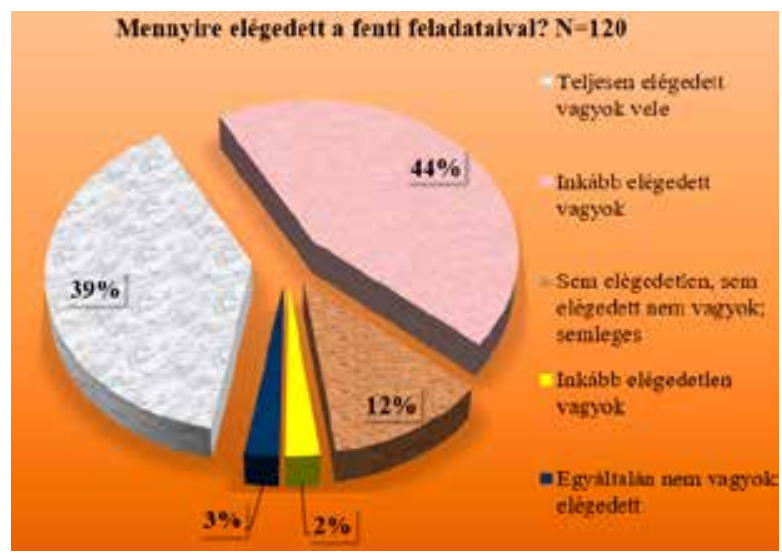

4. ábra

A kutatás során kitértünk arra a kérdésre is, hogy a válaszadók életében milyen szinten és mértékben van jelen a szerencsejáték. Megállapítható, hogy megkérdezettek 36,4\%-a játszik valamilyen szerencsejátékot, az igennel válaszolók jelentős része $(97,2 \%)$ lottózik, és 27,8\%-uk vásárol kaparós sorsjegyet. Azonban a költéseik roppant szerények, és a válaszadók körében még soha nem fordult elő, hogy többet költöttek volna szerencsejátékra, mint eredetileg tervezték.

„Az idős kor értelme a megtalált, fellelt új életcélokban és a tevékeny életben rejlik. Az életenergiák feltöltődését az elfogadás, a szeretet, a kapcsolatok megléte, a társas életforma fenntartása biztosíthatja, mely hatására új életcélok, feladatok, hasznos tevékenységek fogalmazódhatnak meg és kaphatnak szerepet a mindennapokban" (Fritz, 2011, 187.). A reális tervek, életcélok meghatározása és ennek elérésére való törekvés léte álláspontunk szerint felértékelődik a nyugdíjas korúak körében. Éppen ezért tartottuk fontosnak, hogy megismerjük a megkérdezettek vágyait, életcéljait, saját motivációjukat

A válaszadók - 155 fó - 84,5\%-a tele van tervekkel, vágyakkal, további életcélokkal. Lehetőséget biztosítottunk a válaszadóknak arra, hogy rövid szóbeli válasszal megosszák velünk ezen motivációjukat. A szöveges válaszokat eddig alapvetően két csoportra lehet osztani. Az egyikben a saját életét érintő, személyes vágyak jelennek meg, amelyek lelki-érzelmi jellegủek úgymint: egészségük megörzése, látni azt, ahogyan az unokája lediplomázik, mindennapok elviselhetővé tétele betegségük mellett stb. Ezzel párhuzamosan a második csoportba fizikai aktivitáshoz köthető célokat olvashattunk, úgymint: kirándulás, utazás (külföldön/Magyarországon), zarándokutak, nyelvtanulás.

Bár sajnos egészségügyi problémákkal erősen terheltek, ráadásul közeli hozzátartozó elvesztése is igen gyakori, azonban várakozásainkkal ellentétben, egy-egy családi trauma nem okozott a megkérdezettek zöménél lényeges törést az életvitelben, valamint a szabadidöfelhasználás módjában.

További kutatás tárgyát fogja képezni annak a kimutatása, hogy milyen statisztikai kapcsolat van (ha van) az elfoglaltság, élettervek, valamint az egészségi állapot és szellemi-fizikai aktivitás között.

\section{Következtetések és összegzés}

Bár - statisztikai értelemben - jóval tovább élünk, mint elődeink, mégis arra vonatkozóan, hogy hogyan is éljünk ezzel a lehetőséggel, már nehezebb megfelelő választ találni. Míg mondjuk ,a Távol-Keleten az emberek egész életük során aktív életet élnek, ezért miközben egyre idősebbek lesznek, gyakran nyerik vissza az életerejüket és a fiatalság érzését. Nem csoda, ha valaki akár 20 évvel fiatalabbnak néz ki valódi koránál. Egy általánosan elfogadott nézet szerint minden megélt év egy további lépés az öregség és a vitalitás és a bölcsesség felé.” (Katona, 2003, 7. o.) Addig „hazánkban az idős emberek (sem) rendelkeznek olyan protektív magatartásmintákkal, melyek segítenének a testi-lelki egészség megőrzésben. Az idős és az idősödő korosztály előtt nincs olyan társadalmilag kialakított példa, hogy jó-e és ha igen, mért jó idősnek lenni. Ehhez kapcsolódóan pedig, hogyan lehet eltölteni minél hatékonyabban, teljesebben a rendelkezésére álló nyugdíjas éveket, ugyancsak nehéz megfelelő választ adni (Nagyváradi és tsi., 2012, 45. o.)."

A harmadik életszakasz minél tudatosabb, minél teljesebb megélésében kulcsfontosságú kérdés, hogy nyugdíjasaink hogyan tudnak gazdálkodni a rendelkezésükre álló szabadidejükkel, hogyan fogják tudni megőrizni mind szellemi, mint pedig fizikai aktivitásukat, valamint hogyan tudják betölteni a családban lévő helyüket és ezzel kapcsolatos szerepkörüket.

A kulturális sajátosságok mellett mindenképpen meg kell említenünk az anyagi helyzet szerepét és a vidék-nagyváros beli különbségeket, melyeket a későbbiek során részletezni és kimutatni érdemes.

Kutatásunkat elsődlegesen gondolatébresztőnek szántuk, amelynek során további kutatásra alkalmas eredményeket kaptunk. Bár mintánk nem tekinthető reprezentatívnak, mégis a mind szellemi, mind fizikai téren aktív, az internetet rendszeresen használó, az új technikai eszközök megismerésére nyitott nyugdíjas korcsoporttól kaptunk értékes válaszokat.

Köszönetet mondunk dr. Hegyesiné Orsós Éva volt helyettes államtitkár aszszonynak értékes tanácsaiért és segítségéért. (tessenyi.judit@eco.u-szeged.hu)

\section{Irodalomjegyzék}

Bárdosi, M. - Tabajdi, M.: Kulturális szokásaink (2013). Központi Statisztikai Hivatal, Budapest Bodrogi, J. (2009): Az idősödés néhány demográfiai, közgazdasági és társadalombiztosítási összefüggése. LAM Lege Artis Medicinae. 19. 8-9. 527-530. o. From: http://www.elitmed.hu/upload/pdf/az_idosodes_nehany_demografiai_kozgazdasagi_es_tarsadalombiztositasi_osszefuggese-4437.pdf (2016. 09. 12.)

Demográfiai évkönyv 1974 (1975). Központi Statisztikai Hivatal, Budapest
Demográfiai évkönyv 2013 (2014). Központi Statisztikai Hivatal, Budapest

Európai Bizottság öregedésre vonatkozó szakpolitikájának hivatalos oldala: From: http:// ec.europa.eu/health/ageing/policy/index hu.htm

Fritz, P. (2011): Mozgásos rekreáció. Bába Kiadó, Szeged

Iván, L. (2005): Az idősödés és időskor, mint az edzettség próbája. In: Némethné Jankovics Györgyi (szerk.): Aktivitás - Mozgás - Sport a harmadik életszakaszban. Szenior Könyvek, Győr, 7-18. o.

Iván, L. (2002): Az öregedés élettani és társadalmi jelenségei. Magyar Tudomány 108.
4. 412-418. o. From: http://www.matud.iif. hu/02apr/ivan.html (2016. 09. 12.)

Időmérleg 2009/2010 Összefoglaló adattár (2012). Központi Statisztikai Hivatal, Budapest Katona, V. (2003): Érezzük jól magunkat idős korban! (2003), Szenior Könyvek, Győr

Nagyváradi, K. - Kiss-Geosits, B. - Polgár, T. - Tasnády, F. (2012): Miért jó idősnek lenni. rekreacio.eu. 2012. február. II. 1. szám. 39-45. o.

2011-es népszámlálás, iskolázottságra vonatkozó adatai: From: http://www.ksh.hu/nepszamlalas/tablak_iskolazottsag 